\title{
Efficient use of energy through organic rice-duck mutualism system
}

\author{
Hemmatollah Pirdashti ${ }^{1}$ Mohsen Pirdashti ${ }^{2} \cdot$ Mahmood Mohammadi $^{3}$. \\ Mohammad Gharavi Baigi ${ }^{3}$ - Kamyar Movagharnejad ${ }^{2}$
}

Accepted: 26 April 2015 /Published online: 8 July 2015

(C) INRA and Springer-Verlag France 2015

\begin{abstract}
Industrial agriculture is not efficient anymore due in particular to the use of nonrenewable energy such as fossil fuels. Organic agriculture is an alternative system that aims to reduce the consumption of fossil fuels, pesticides, and mineral fertilizers. Animal-crop systems present potential mutual benefits, but such systems have been rarely studied quantitatively. Here, we compare energy inputs and outputs of organic riceduck farming with conventional rice production in Mazandaran province, Iran. Our results show that the global energy input of organic rice-duck, 79,307 $\mathrm{MJ} \mathrm{ha}^{-1}$, is lower than that of conventional rice, 94,377 $\mathrm{MJ} \mathrm{ha}^{-1}$. On the contrary, the energy output of organic rice-duck, 117, $325 \mathrm{MJ} \mathrm{ha}^{-1}$, is higher than that of conventional rice, 111, $914 \mathrm{MJ} \mathrm{ha}^{-1}$. The most used energy was fuel, amounting to $40 \%$ of total energy for organic rice-duck and $33 \%$ for conventional rice. Then, machinery consumed $25 \%$ of total
\end{abstract}

Hemmatollah Pirdashti

h.pirdashti@sanru.ac.ir

Mohsen Pirdashti

pirdashti@yahoo.com

Mahmood Mohammadi

mahmood.mohammadi48@yahoo.com

Mohammad Gharavi Baigi

en_gharavi@yahoo.com

Kamyar Movagharnejad

Movagharnejad@yahoo.com

1 Agronomy Department, Genetics and Agricultural Biotechnology Institute of Tabarestan, Sari Agricultural Sciences and Natural Resources University, Sari, Iran

2 Faculty of Chemical Engineering, Babol University of Technology, PO Box, 484, Babol, Iran

3 Agronomy Department, Sari Agricultural Sciences and Natural Resources University, Sari, Iran energy for organic rice-duck and $20 \%$ for conventional rice. Then, fertilizers consumed $20 \%$ of total energy in the form of organic fertilizers for organic rice-duck versus $16 \%$ in the form of mineral fertilizers for conventional rice. Overall, our findings show that organic rice-duck farming has more energy efficiency than conventional rice farming.

Keywords Renewable energy $\cdot$ Rice $\cdot$ Rice-duck . Sustainable agriculture $\cdot$ Mutualism

\section{Introduction}

Population growth is believed to be one of the main challenges for the future of human civilization (Kibirige 1997; Swaminathan 2010). Although extensive population control programs have been successfully performed in many countries, the world's population has doubled since 1960 and is still increasing (Gilland 2002). One of the main challenges of population growth is food shortage caused by limited resources and the limitations of traditional agriculture, which was a main concern of the classical Malthusian approach. Fortunately, modern agriculture has successfully attacked the problem by developing more efficient techniques, such as using more efficient plant and animal varieties, increasing the use of fertilizers, extending irrigation, effectively controlling insects and diseases, and so on (Guangyong et al. 2011; Mosher and Corscadden 2012; Sarkar et al. 2012). It seems that modern agriculture is able to solve this problem and feed the increasing population, and it is hoped that equilibrium will be reached in the current century. The employment of these modern agricultural policies, however, demands higher amounts of energy. It is well known that modern farming is very energy intensive (Singh et al. 2000). The future of human civilization still faces the challenge of energy, and it seems that 
modern agriculture has exacerbated this challenge by widely using nonrenewable energy sources such as fossil fuels, especially for operating farm and irrigation machinery, producing chemical fertilizers, pesticides, and herbicides and using electrical inputs which may be produced by fuel consumption in power plants.

Modern agriculture has also to face the paradoxical problem of eco-efficient and sustainable production. Some researchers have reported the substantial share held by modern agriculture of the emission of trace greenhouse gases (Isermann 1994; Yuksel and Kaygusuz 2011). Therefore, methods of decreasing the energy needs of modern, energy-intensive agriculture must be found. Some researchers claim that the use of renewable energy may reduce the consumption of fossil fuels (Panwar et al. 2011; Ong et al. 2011; Hasan et al. 2012; Bardi et al. 2013). Efficiency in energy use has also been reported to minimize many of these problems by saving natural resources and leading to sustainable agriculture (Kizilaslan 2009; Ozkan et al. 2011a, b). Organic agriculture, which has been widely studied in recent years, is believed to lower energy consumption and balance long-term productivity with ecological sustainability (Lund and Algers 2003; Mingl and Sauerborn 2006). According to International Federation of Organic Agriculture Movements (IFOAM) definition, organic farming is free of agricultural chemicals, such as synthetic chemical fertilizers and pesticides, with the exception of certain permitted chemicals including lime sulfur and low-synthetic minerals (http://www.ifoam.bio/, Hokazono and Hayashi 2012).

Rice (Oryza sativa L.) is cultivated in many parts of the world and is the second most-produced grain in the world. Since this grain requires plenty of water and labor, it is believed that it consumes much energy. Areas which have high rainfall and low labor costs, such as East, South, and Southeast Asia and certain regions of the Middle East, are considered most suitable for rice production. Rice is cultivated under different soil, water, and temperature conditions (PishgarKomleh et al. 2011; Chauhan et al. 2006).

In Iran, the agriculture sector contributed significantly to the GDP (11.9\%) in 2011, and rice was considered one of the country's most important and strategic crops (http://www. imna.ir). Iran's arable area is $17,541,000$ ha, of which 574,000 ha $(3.27 \%)$ were rice fields in 2011. In 2011, rice produced in Iran equaled more than $2.7 \mathrm{Mt}$ of the $728.7 \mathrm{Mt}$ produced worldwide. The 2011 worldwide average yield of rice was $4300 \mathrm{~kg} \mathrm{ha}^{-1}$; however, the average rice yield in Iran was almost $4478.2 \mathrm{~kg} \mathrm{ha}^{-1}$. That year, Mazandaran province ranked first in total rice crop production share in Iran (46.3\%) (Food and Agriculture Organization FAO of the United Nation Statistics 2013; Annual agricultural statistics. Availablefrom. Ministry of Jihad-e- Agriculture of Iran 2013). According to FAO (2012) reports, among the main countries now expected to cut imports from the previous year are China, Indonesia, the Islamic Rep. of Iran, Nigeria, the Philippines, Senegal, and
Thailand. Iran has many reasons to cut imports, e.g., independent political property, increased energy costs, unemployment problems, etc. Thus, efforts are immediately required not only to improve rice crop production but also to decrease the associated direct and indirect costs by lessening pollution and preventing environmental problems such as nitrate leaching and eutrophication. Based on these important reasons, one of Iran's main agriculture strategies is to implement organic and sustainable agriculture. Today, Iran has begun spatially converting conventional rice monocropping patterns to different multiple cropping rice-based systems, like the rice/green manure or rice-duck organic farming systems. According to FAO (2012) reports, Iran with 43,332 ha was the sixth country with the most organic agricultural land in 2011 behind China, India, Kazakhstan, the Philippines, and Indonesia.

Rice-duck farming, a form of organic agriculture, has many economic, environmental, and ecological benefits ( $\mathrm{Li}$ et al. 2012). Since the harmful effects of the intensive employment of agrochemicals and chemical fertilizers in commercial agricultural systems were highlighted by numerous researches worldwide, the integrated rice-duck system has been recommended into cultivation practices in many Asian countries, particularly Japan, China, Indonesia, Vietnam, Korea, and the Philippines. This system creates a yield-increasing model of integrated utilization of paddy resources for rice production and, more importantly, duck breeding. Thus, a mutually beneficial situation is established for both rice growing and duck breeding in this system rather than a simple combination (Xi and Qin 2009; Pin et al. 2012). A number of studies have compared the rice-duck mutualism organic farming as an organic farming system to conventional cultivation methods with respect to environmental and ecological issues. Their findings attribute high advantages to this system because of the reduction in expenses of herbicides, insecticides, fungicides, and chemical fertilizers which are replaced with duck manure and the foraging behavior and frequent movements of ducks, which effectively control weeds and insects (Takayama et al. 2004; Li et al. 2008; Zhan et al. 2011). Huang et al. $(2005,2008)$ investigated the effects of a rice-duck complex ecosystem on methane emission. They found that the rice-duck ecological planting and breeding model significantly decreased methane emissions from paddy fields compared with conventional rice fields. $\mathrm{Li}$ et al. (2012) reported the efficacy of the rice-duck mutualism organic farming in depleting weed seed banks and as a weed management approach without the use of herbicides.

Factors which influence the economy of conventional crops are directly related to energy. Quantitative relations show how the system's benefits and costs are affected by energy consumptions. Determining energy efficiency has been the main subject of the majority of previous studies (e.g., Singh et al. 2000; Karkacier and Goktolga 2005; Rafiee et al. 2010; Zangeneh et al. 2010; Pahlavan et al. 2011; Bojacá et al. 2012; Tabatabaie et al. 2013). Some studies have published energy and economic analyses of rice crop alone (Pishgar-Komleh et al. 2011). 
Many studies compare the different aspects of organic and conventional rice production methods. This work aimed to investigate the energy and economic aspects which are usually ignored. Factors such as energy productivity, different energy ratios, and so on are studied, and economic values are related to environmental issues.

\section{Materials and methods}

\subsection{Site description and climatic data}

The current study was conducted in the Mazandaran province of northern Iran, along the southern coast of the Caspian Sea (Fig. 1), which has an altitude of $16 \mathrm{~m}$ above sea level. This province is located between $35^{\circ} 46^{\prime}$ and $36^{\circ} 58^{\prime}$ lat. $\mathrm{N}$ and $21^{\circ}$ $50^{\prime}$ and $54^{\circ} 08^{\prime}$ long. E. The climate of the area (data relating to the years 2001-2012) is characterized by an annual average rainfall of $1315.5 \mathrm{~mm}$, distributed mostly in autumn and winter. Annual average temperatures are $7-32{ }^{\circ} \mathrm{C}$, with a monthly maximum ranging between 23 and $35^{\circ} \mathrm{C}$ in July and a minimum of $3-20{ }^{\circ} \mathrm{C}$ in January. During the study period, annual precipitation measured $877.20 \mathrm{~mm}$ in 2011 and $1706.4 \mathrm{~mm}$ in 2012. Soil analysis showed soil texture to be clay and clay loam. Mazandaran province was selected for this research because it is the number one rice cultivating area in Iran ( $46.3 \%$ of the country's area).

\subsection{Experimental details and sampling procedure}

Experimental data for the 2011-2012 period was gathered from different rice-producing plants regarding 112 cases in 23 different villages of Mazandaran province. The average

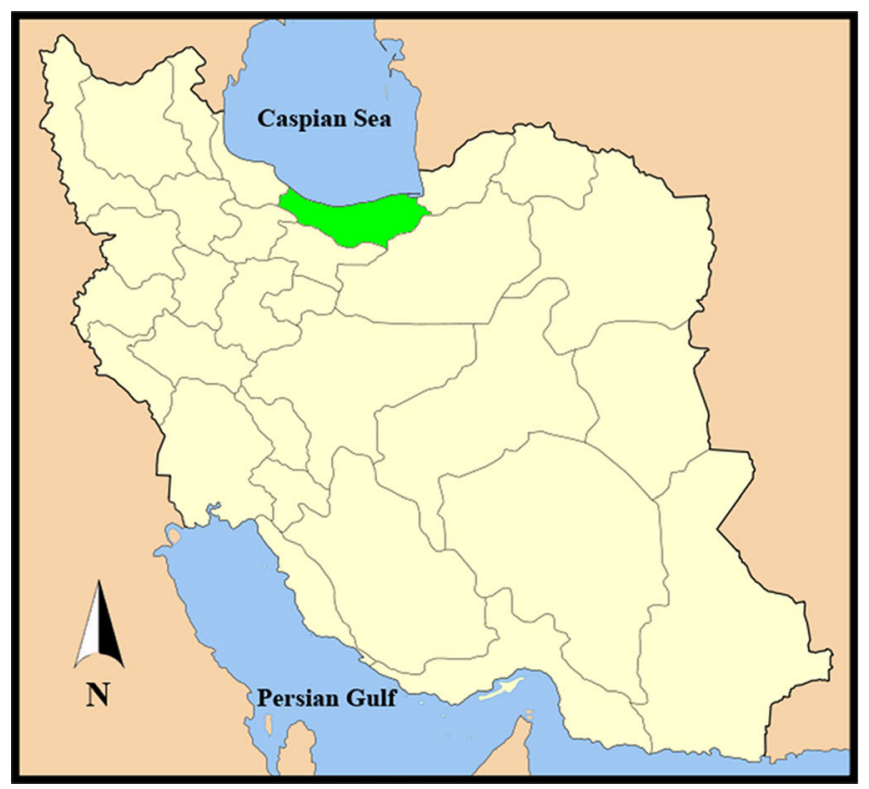

Fig. 1 Map of Iran showing the location of Mazandaran province area of the studied cases was $0.8 \mathrm{ha}$, and both single rice and rice-duck farming cases were considered.

The survey volume was determined by the simple random sampling method (Yates et al 2008; Ghasemi Mobtaker et al. 2010):

$n=\frac{N \times s^{2} \times t^{2}}{(N-1) t^{2}+s^{2} \times t^{2}}$

where $n$ is the required sample size, $s$ is the standard deviation, $t$ is the $t$ value at a $95 \%$ confidence level (1.96), $N$ is the number of holding in target population, and $d$ is the acceptable error (permissible error $5 \%$ ).

\subsection{Data mining}

The inputs considered for these two modes were human labor, machinery, diesel fuel, chemical fertilizers, pesticides, fungicides, and herbicides as biocides, water for irrigation, seed, rice bran, and duckling. The outputs considered were grain, straw, and duck as a product. The input and output amounts utilized in two rice production systems are presented in Table 1 .

Human energy as an energy input was calculated by multiplying the number of man-hours $\left(\mathrm{hha}^{-1}\right)$ based on the estimated power rating of human labor $\left(\mathrm{MJh}^{-1}\right)$ from Table 1 . The energy used by machinery was estimated as follows (Kitani et al. 1999):

$\mathrm{ME}=E \times G \times T$

where $\mathrm{ME}$ is the machinery energy (MJ), $E$ is the production energy of the machine (Table 1), $G$ is the mass of the machine

CASPIAN SEA

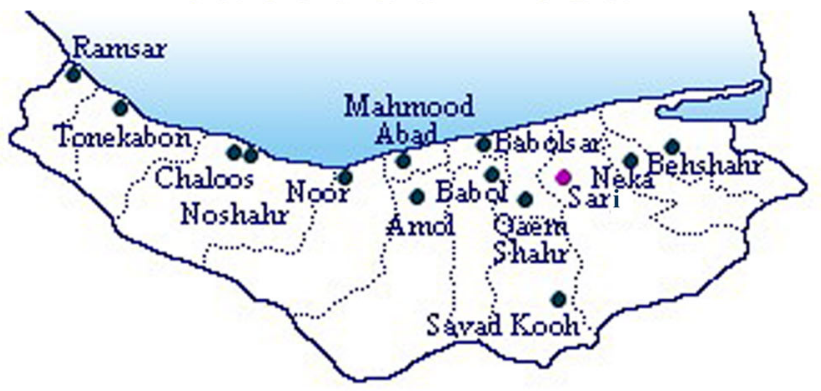


Table 1 Energy equivalent of inputs and output in two different rice production systems

\begin{tabular}{|c|c|c|c|}
\hline Input & Unit & $\begin{array}{l}\text { Energy equivalent } \\
\text { (MJunit }^{-1} \text { ) }\end{array}$ & References \\
\hline \multicolumn{4}{|l|}{ A. Inputs } \\
\hline 1. Machinery & $\mathrm{h}$ & 62.70 & $\begin{array}{l}\text { Royan } \\
\text { et al.(2012), } \\
\text { Agha Alikhani } \\
\text { et al.(2013) }\end{array}$ \\
\hline \multicolumn{4}{|l|}{ 2. Human labor } \\
\hline Male & $\mathrm{h}$ & 1.96 & $\begin{array}{l}\text { Sing et al.(1994), } \\
\text { Agha Alikhani } \\
\text { et al.(2013), }\end{array}$ \\
\hline Female & $\mathrm{h}$ & 1.54 & Sing et al.(1994) \\
\hline 3. Diesel & $\mathrm{L}$ & 56.31 & $\begin{array}{l}\text { Agha Alikhani } \\
\text { et al.(2013) }\end{array}$ \\
\hline 4. Chemical fertilizer & - & & \\
\hline Nitrogen $(\mathrm{N})$ & $\mathrm{kg}$ & 66.14 & Kitani (1999) \\
\hline Phosphorus $\left(\mathrm{P}_{2} \mathrm{O}_{5}\right)$ & $\mathrm{kg}$ & 12.44 & Kitani (1999) \\
\hline Potassium $\left(\mathrm{K}_{2} \mathrm{O}\right)$ & $\mathrm{kg}$ & 11.50 & Kitani (1999) \\
\hline Zinc (Zn) & $\mathrm{kg}$ & 8.40 & $\begin{array}{l}\text { Agha Alikhani } \\
\text { et al.(2013) }\end{array}$ \\
\hline 5. Organic fertilizer & ton & 303.10 & $\begin{array}{l}\text { Rai Jadidi } \\
\text { et al.(2010) }\end{array}$ \\
\hline 6. Biocide & - & & \\
\hline Insecticide & $\mathrm{kg}$ & 229.00 & Kitani (1999) \\
\hline Herbicide & $\mathrm{kg}$ & 85.00 & Kitani (1999) \\
\hline Fungicide & $\mathrm{kg}$ & 115.00 & Kitani (1999) \\
\hline 7. Seed & $\mathrm{kg}$ & 14.70 & Kitani (1999) \\
\hline 8. Rice bran & $\mathrm{kg}$ & 12.55 & Sayin et al.(2005) \\
\hline 9. Water & $\mathrm{m}^{3}$ & 1.02 & $\begin{array}{l}\text { Agha Alikhani } \\
\text { et al.(2013) }\end{array}$ \\
\hline 10. Duckling & $\mathrm{kg}$ & 14.10 & William (2008) \\
\hline \multicolumn{4}{|l|}{ B. Outputs } \\
\hline 1. Paddy rice & $\mathrm{kg}$ & 14.70 & $\begin{array}{l}\text { Agha Alikhani } \\
\text { et al.(2013) }\end{array}$ \\
\hline 2. Straw & $\mathrm{kg}$ & 12.50 & $\begin{array}{l}\text { Agha Alikhani } \\
\text { et al.(2013) }\end{array}$ \\
\hline 3. Duck & $\mathrm{kg}$ & 14.10 & William (2008) \\
\hline
\end{tabular}

$(\mathrm{kg})$, and $T$ is the economic life of the machine (years). Other inputs such as fuel, seed, biocides, and chemical fertilizers used in rice production were transformed to energy value (MJha ${ }^{-1}$ ) by multiplying the quantity of the material used on the farms by the energy equivalent of each material. For example, the energy consumed to produce chemical fertilizer (potassium) was calculated by multiplying the amount of potassium usage $\left(\mathrm{kg} \mathrm{ha}^{-1}\right)$ by the energy coefficient of potassium fertilizer production (12.44 $\mathrm{MJkg}^{-1}$ from Table 1); the result is the energy consumption of potassium fertilizer $\left(\mathrm{MJha}^{-1}\right)$ in rice production. Other energy inputs can be similarly estimated. Since gasoline pumps are used to prepare irrigation water, irrigation energy was displayed as diesel energy. The amount of output energy ( $\mathrm{MJ} \mathrm{ha}^{-1}$ ) was estimated by multiplying the rice paddy yield $\left(\mathrm{kg} \mathrm{ha}^{-1}\right)$ by the rice energy equivalent
(MJ kg ${ }^{-1}$ ). The total input equivalent can be calculated by adding up the energy equivalences of all inputs in mega joules (MJ). Based on the energy equivalents of the inputs and output (Table 2), the energy ratio (energy use efficiency) and energy productivity were calculated as follows (Hülsbergen et al. 2001; Yilmaz et al. 2005; Demircan et al. 2006; Shahan et al. 2008):

Energy use efficiency $=\frac{\text { Energy Output }\left(\mathrm{MJ} \mathrm{ha}^{-1}\right)}{\text { Energy Input }\left(\mathrm{MJ} \mathrm{ha}^{-1}\right)}$

Energy productivity $=\frac{\text { Production }\left(\mathrm{kg} \mathrm{ha}^{-1}\right)}{\text { Energy Input }\left(\mathrm{MJ} \mathrm{ha}^{-1}\right)}$

Specific energy $=\frac{\text { Energy Input }\left(\mathrm{MJ} \mathrm{ha}^{-1}\right)}{\operatorname{Production}\left(\mathrm{kg} \mathrm{ha}^{-1}\right)}$

Net Energy $=$ Energy Output $\left(\mathrm{MJ} \mathrm{ha}^{-1}\right)-$ Energy Input $\left(\mathrm{MJ} \mathrm{ha}^{-1}\right)$

In the last part of the study, total energy input was also classified into either direct and indirect or renewable and nonrenewable forms. Direct energy (DE) included human labor and diesel fuel energy used in the production process, and indirect energy (IDE) consisted of machinery, seed, chemical fertilizer, biocide, organic fertilizer, rice bran, water, and duckling and duck energy. Renewable energy (RE) consisted of seed and human labor, organic fertilizer, rice bran, water, duckling and duck; nonrenewable energy (NRE) included machinery, diesel fuel, biocides, and chemical fertilizers. The term 'renewable energy' refers to energy sources that are replenished by natural processes on a sufficiently rapid timescale; they can be used by humans more or less indefinitely, provided the quantity taken per unit of time is not too great. The term 'nonrenewable energy' is used to describe energy sources that exist in limited amounts on earth (Singh et al. 2003; Tabatabaie et al. 2013). The data were subjected to SPSS, version 18, and $t$ test was used to compare two systems $(P<0.05$ was considered statistically significant).

\section{Results and discussion}

All inputs and outputs for the rice-duck mutualism organic farming and the conventional rice cultivation are shown in Table 2. Human labor for the rice-duck mutualism farming system was determined to be about $267.9 \mathrm{~h}$, which $155.4 \mathrm{~h}$ for male and $112.5 \mathrm{~h}$ for female, while for conventional rice cultivation system was determined to be about $240.1 \mathrm{~h}(180.0 \mathrm{~h}$ for male and $60.06 \mathrm{~h}$ for female). The human labor for the rice-duck mutualism farming system was greater than conventional rice cultivation system. One of the main reason 
Table 2 Amounts of used inputs and outputs and their energy equivalences in two rice production systems

\begin{tabular}{|c|c|c|c|c|c|c|c|c|}
\hline \multirow{2}{*}{\multicolumn{2}{|c|}{ Input }} & \multicolumn{3}{|c|}{ Rice-duck mutualism organic farming } & \multicolumn{3}{|c|}{ Conventional rice cultivation } & \multirow{2}{*}{$\begin{array}{l}T \text { test } \\
\text { significance }\end{array}$} \\
\hline & & $\begin{array}{l}\text { Quantity per unit } \\
\text { area (ha) }\end{array}$ & $\begin{array}{l}\text { Energy equivalent } \\
\left(\mathrm{MJ} \mathrm{unit}^{-1}\right)\end{array}$ & Percentage & $\begin{array}{l}\text { Quantity per unit } \\
\text { area (ha) }\end{array}$ & $\begin{array}{l}\text { Energy equivalent } \\
\left(\mathrm{MJ} \mathrm{unit}^{-1}\right)\end{array}$ & Percentage & \\
\hline \multicolumn{9}{|c|}{ A. Inputs } \\
\hline 1. & Machinery (h) & $313.3 \pm 7.40$ & $19,643 \pm 464$ & 24.77 & $302.1 \pm 7.64$ & $18,941 \pm 479$ & 20.07 & 0.955 \\
\hline \multirow[t]{3}{*}{2.} & $\begin{array}{l}\text { Human Labor } \\
\text { (h) }\end{array}$ & $267.9 \pm 28.7$ & $478 \pm 44$ & 0.6 & $240.1 \pm 6.17$ & $445 \pm 11$ & 0.47 & 0.000 \\
\hline & Male (h) & $155.4 \pm 8.09$ & $305 \pm 16$ & 0.38 & $180.0 \pm 5.07$ & $352 \pm 10$ & 0.37 & 0.013 \\
\hline & Female (h) & $112.5 \pm 30.9$ & $173 \pm 31$ & 0.22 & $60.06 \pm 3.70$ & $93 \pm 4$ & 0.10 & 0.015 \\
\hline 3. & Diesel (L) & $561.5 \pm 6.2$ & $31,616 \pm 351$ & 39.87 & $554.5 \pm 6.9$ & $31,168 \pm 387$ & 33.02 & 0.837 \\
\hline \multirow[t]{5}{*}{4.} & $\begin{array}{l}\text { Chemical } \\
\text { fertilizer }(\mathrm{kg})\end{array}$ & 0.00 & 0 & 0.00 & $359.90 \pm 20.7$ & $15,042 \pm 1352$ & 15.94 & 0.008 \\
\hline & Nitrogen $(\mathrm{N})$ & 0.00 & 0 & 0.00 & $198.17 \pm 20.2$ & $13,107 \pm 1340$ & 13.89 & 0.008 \\
\hline & $\begin{array}{l}\text { Phosphorus } \\
\left(\mathrm{P}_{2} \mathrm{O}_{5}\right)\end{array}$ & 0.00 & 0 & 0.00 & $96.50 \pm 2.1$ & $1200 \pm 26$ & 1.27 & 0.000 \\
\hline & Potassium $\left(\mathrm{K}_{2} \mathrm{O}\right)$ & 0.00 & 0 & 0.00 & $60.12 \pm 1.83$ & $691 \pm 21$ & 0.73 & 0.000 \\
\hline & Zinc (Zn) & 0.00 & 0 & 0.00 & $5.11 \pm 1.05$ & $43 \pm 8$ & 0.05 & 0.000 \\
\hline 5. & $\begin{array}{l}\text { Organic fertilizer } \\
\text { (ton) }\end{array}$ & $3.00 \pm 0.92$ & $909 \pm 280$ & 1.15 & 0.00 & 0 & 0.00 & 0.000 \\
\hline \multirow[t]{4}{*}{6.} & Biocide (kg) & 0.00 & 0 & 0.00 & $12.02 \pm 0.93$ & $1842 \pm 196$ & 1.95 & 0.000 \\
\hline & Insecticide & 0.00 & 0 & 0.00 & $5.22 \pm 0.83$ & $1195 \pm 190$ & 1.27 & 0.000 \\
\hline & Herbicide & 0.00 & 0 & 0.00 & $4.50 \pm 0.27$ & $383 \pm 23$ & 0.41 & 0.000 \\
\hline & Fungicide & 0.00 & 0 & 0.00 & $2.30 \pm 0.27$ & $265 \pm 31$ & 0.28 & 0.000 \\
\hline 7. & Seed (kg) & $36.20 \pm 2.3$ & $532 \pm 34$ & 0.67 & $36.20 \pm 2.07$ & $532 \pm 30$ & 0.56 & 0.961 \\
\hline & Rice bran (kg) & $1250.00 \pm 28.6$ & $15,688 \pm 358$ & 19.78 & 0.00 & 0 & 0.00 & 0.000 \\
\hline & Water $\left(\mathrm{m}^{3}\right)$ & $7585.60 \pm 18.4$ & $8900 \pm 18.8$ & 11.22 & $7737.31 \pm 516.5$ & $9078 \pm 527$ & 9.62 & 0.422 \\
\hline 10. & Duckling (kg) & $75.42 \pm 4.40$ & $1063 \pm 62$ & 1.34 & 0.00 & 0 & 0.00 & 0.000 \\
\hline Tot: & l energy input & - & 79,307 & 100.00 & - & 94,377 & 100.00 & \\
\hline \multicolumn{9}{|c|}{ B. Outputs } \\
\hline 1. & Grain (kg) & $5500.65 \pm 156.17$ & $80,860 \pm 825$ & 68.92 & $5435.42 \pm 146.2$ & $79,901 \pm 727$ & 71.39 & 0.000 \\
\hline & Straw (kg) & $2559.12 \pm 124.5$ & $29,377 \pm 306$ & 25.04 & $2561.03 \pm 122.8$ & $32,013 \pm 105$ & 28.60 & 0.020 \\
\hline & Duck (kg) & $502.69 \pm 14.9$ & $7088 \pm 210$ & 6.04 & 0.00 & 0.00 & 0.00 & 0.000 \\
\hline \multicolumn{2}{|c|}{ Total energy output } & 8562.46 & 117,325 & 100.00 & 7996.45 & 111,914 & 100.00 & \\
\hline
\end{tabular}

Value in italic indicate total energy input and output of two production systems

was duck farming is labor-intensive. Also, the ratio of female to male workers in the rice-duck mutualism organic farming was bigger than the conventional rice cultivation. Duck farming was held by female labor. It will be a positive note that women are more active in the social economy. Machinery power was estimated to be around 313.3 and $302.1 \mathrm{~h} \mathrm{ha}^{-1}$ for the rice-duck mutualism organic farming and the conventional rice cultivation system, respectively. The amount of diesel fuel required for the conventional rice cultivation or the rice-duck mutualism organic farming production was about 561.5 and $554.5 \mathrm{~L}$, respectively. The total amounts of fertilizers and biocides used for the conventional rice cultivation and rice production were 359.90 and $12.02 \mathrm{~kg} \mathrm{ha}^{-1}$, respectively. Ducks tend to move about as they forage, and the rice-duck mutualism organic farming takes advantage of this habit to control plant diseases, insect pests, and weeds and to increase both rice production and income (Fig. 2 a, b, c, d). The long-term adverse health and environmental effects of insecticides, herbicides, and chemical fertilizer use were also substantially reduced, thus making the system beneficial to the environment. Only 3 tons of organic fertilizer was used in the rice-duck mutualism organic farming areas; no fertilizers or biocides were used. Moreover, healthier duck meat was produced. Huang et al. (2013) similarly observed that the organic rice-prawn farming yields $20 \%$ higher revenues.

It can be concluded that the rice-duck mutualism organic farming producer may obtain dual benefits from the simultaneous production of rice and duck meat. Hong et al. (2009) compared the quality of meat produced by rice-duck mutualism and conventional duck production. They found the rice-duck mutualism system could significantly improve the quality of both duck meat and duck carcass. The total averages for energy 
Fig. 2 a Duckling, b weed and pest control, $\mathbf{c}$ soil fertility, and $\mathbf{d}$ ready-for-sale or marketable duck in the rice-duck mutualism system
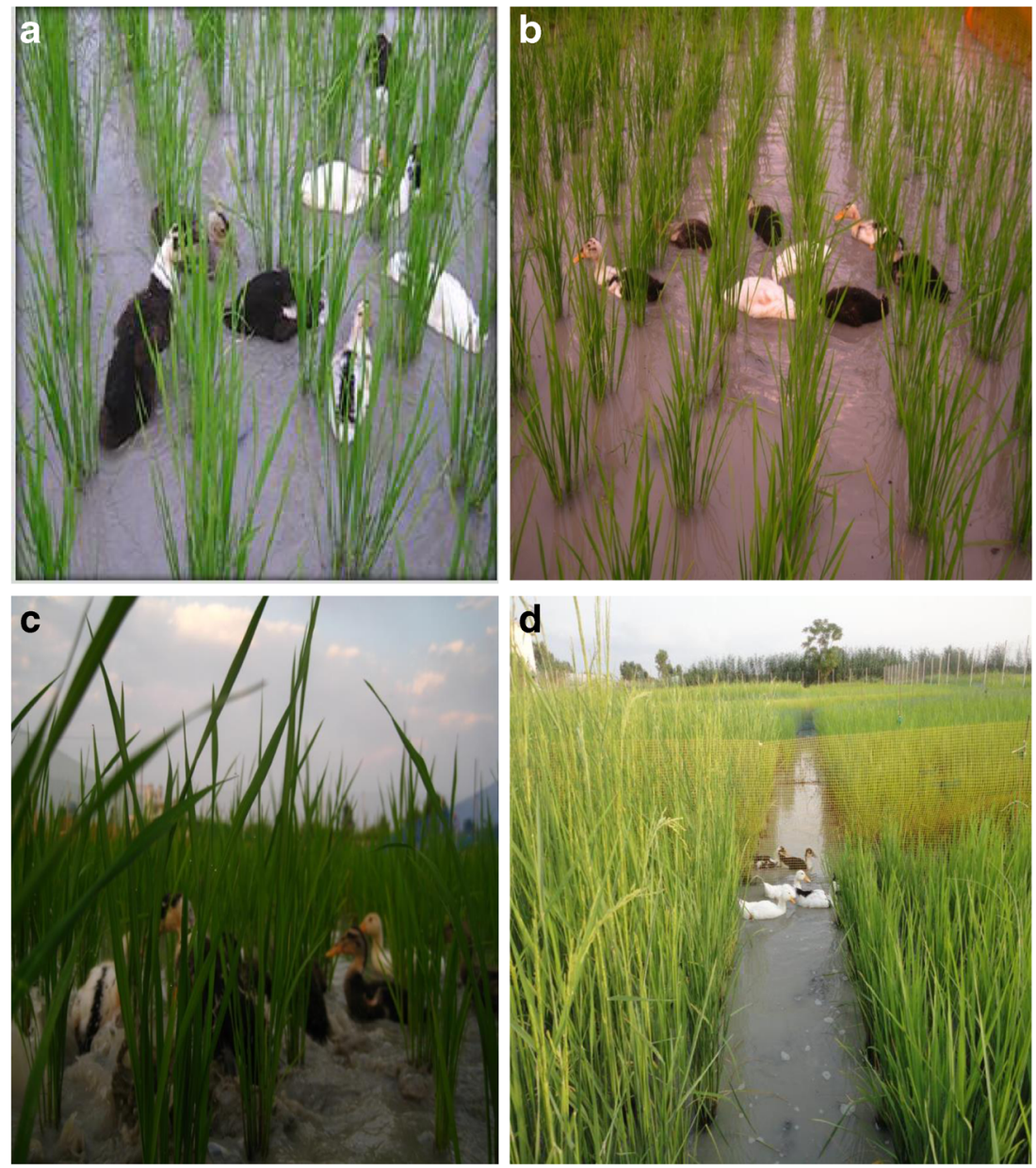

input and output in the rice-duck mutualism organic farming and the conventional rice cultivation were calculated as 79,307 and 117,325 MJ ha ${ }^{-1}$ and 94,377 and 111,914 MJ ha ${ }^{-1}$, respectively. The results showed that the rice-duck mutualism organic farming produced greater energy outputs and used less energy inputs than the conventional rice cultivation.

Fuel consumption comprised the highest energy input in the both systems, being $39.87 \%$ for the rice-duck mutualism organic farming and $33.02 \%$ for the conventional rice cultivation and used mainly to irrigate and operate tractors and other machinery. The low price of hydrocarbon fuels in Iran usually leads to overconsumption of energy due to oversupplying water to rice plantations.

Other researchers have also reported that fuel inputs comprise an important section of energy consumption in rice production and that machine power has replaced human and animal labor (Eskandari Cherati et al. 2011; Pin et al. 2012). The age of the machinery and equipment used may be one reason for poor energy efficiency in rice production in Iran, and this may be improved by applying more efficient machinery and equipment. Table 2 shows that machinery $(24.77 \%$ for the rice-duck mutualism organic farming and $20.07 \%$ for the conventional rice cultivation) constituted the second highest energy consumption item, which included tractors and stationary equipment. The third item is rice bran, accounting for $19.78 \%$ in the rice-duck mutualism organic farming and chemical fertilizers was determined $15.94 \%$ in the conventional rice cultivation. The shares of nitrogen, phosphorus, potassium, and zinc were around $13.89,1.27,0.73$, and $0.05 \%$, respectively. The total amount of biocide energy consumed in the rice-duck mutualism organic farming production was found to be $1.95 \%$, which included $1.27 \%$ for insecticide, $0.41 \%$ for herbicide, and $0.28 \%$ for fungicide. Such efficiency in reducing of chemical fertilizer (up to $52 \% \mathrm{~N}$ fertilizer replaced by biofertilizer) has been previously reported by Huang et al. (2013) in the organic rice-prawn farming system.

Table 3 shows the energy consumption, productivity, and energy gain of various processes in rice production. The energy efficiency of the rice-duck mutualism organic farming $(1.48 \%)$ was somewhat higher than that of the conventional rice cultivation $(1.19 \%)$. Some researchers have used the energy ratio as a measure for energy efficiency in crop production (Kuesters and Lammel 1999). Pishgar-Komleh et al. (2012) reported a ratio of 1.30 for rice production, while Agha Alikhani et al. (2013) reported ratios of 1.72 for traditional and 1.63 for mechanized rice production. The energy productivity 
Table 3 Energy forms and indices in two rice production systems

\begin{tabular}{|c|c|c|c|c|c|c|}
\hline Item & Unit & $\begin{array}{l}\text { Rice-duck mutualism } \\
\text { organic farming }\end{array}$ & $\begin{array}{l}\text { Percentage } \\
(\%)\end{array}$ & $\begin{array}{l}\text { Conventional rice } \\
\text { cultivation }\end{array}$ & $\begin{array}{l}\text { Percentage } \\
(\%)\end{array}$ & $\begin{array}{l}T \text { test } \\
\text { significance }\end{array}$ \\
\hline Energy use efficiency & - & $1.48 \pm 0.02$ & - & $1.19 \pm .003$ & - & 0.000 \\
\hline Energy productivity & $(\mathrm{kgMJ}-1)$ & 0.11 & - & 0.08 & - & - \\
\hline Specific energy & (MJkg-1) & 9.10 & - & 12.50 & - & - \\
\hline Net energy & (MJha-1) & $38,018 \pm 1112$ & - & $17,537 \pm 1072$ & - & 0.000 \\
\hline Direct energy & (MJha) & $32,094 \pm 961.64$ & 40.47 & $31,613 \pm 1238.95$ & 33.50 & 0.000 \\
\hline Indirect energy & (MJha-1) & $46,735 \pm 1333.56$ & 58.93 & $45,435 \pm 1488.24$ & 48.14 & 0.000 \\
\hline Renewable energy & (MJha) & $27,570 \pm 811.16$ & 34.76 & $10,055 \pm 250.08$ & 10.65 & 0.000 \\
\hline Nonrenewable energy & (MJha) & $51,259 \pm 1574.03$ & 64.63 & $66,993 \pm 1715.05$ & 70.98 & 0.000 \\
\hline Total energy input & (MJha) & 79,307 & 100.00 & 94,377 & 100.00 & - \\
\hline
\end{tabular}

Values in italic indicate total energy inputs of two production systems

values of the rice-duck mutualism organic farming and the conventional rice cultivation were found to be 0.11 and $0.08 \mathrm{~kg} \mathrm{MJ}^{-1}$, respectively. The net energy values of the two systems were also calculated to be 38,018 and 17 , $537 \mathrm{MJ} \mathrm{ha}^{-1}$, respectively. This fact indicates that energy is gained in both of these rice production systems. Table 3 shows the different energy parameters in the rice-duck mutualism organic farming and the conventional rice cultivation rice production systems.

This study clearly shows that direct and indirect energy resources are nearly equally utilized. These figures are 40.47 and $58.93 \%$ for the rice-duck mutualism organic farming and 33.50 and $48.14 \%$ for the conventional rice cultivation. The percentages of renewable and nonrenewable energies for the rice-duck mutualism organic farming are 34.76 and $64.63 \%$, respectively. These percentages are quite different for the conventional rice cultivation (10.65 and $70.98 \%$, respectively). This fact shows that a much higher percentage of nonrenewable energy is utilized for the conventional rice cultivation, but these two items are nearly the same for the rice-duck mutualism organic farming.

\section{Conclusion}

Energy analysis was used to evaluate and compare sustainability along with ecological and economic benefits of the riceduck mutualism organic farming versus the conventional rice cultivation and to optimize the rice cultivation-based riceduck mutualism system. The rice-duck mutualism organic farming, a form of organic agriculture, has many economic, environmental, and ecological benefits. According to the results of the current study, the ratio of renewable energy to nonrenewable energy utilized in the rice-duck mutualism organic farming was greater than that in the conventional rice cultivation where the main nonrenewable inputs were chemical fertilizers and biocides. The rice-duck mutualism organic farming can improve the physical structure of paddy soils and suppress weeds using renewable energy resources. This organic farming method has more benefits such as increased or at least maintained soil fertility over the long term, maximized animal welfare, control of air pollution, and restricted stocking densities. Women would have a good opportunity to participate in this activity. Furthermore, it produces healthier and higher quality duck meat and rice than the conventional rice cultivation. This could lead to the development of established sustainability, efficient energy utilization, and environmentally friendly agricultural production systems in the studied area. The results of this research can provide theoretical and practical bases for further optimizing the animal-plant symbiosis pattern and increase the economic benefits for farmers through the effective use of energy and conservation of the ecosystem. Consequently, further assessments on economic and environmental issues are needed to support such a conclusion.

Acknowledgments The authors would like to thank the farmers in the research area for their cooperation. The valuable comments made by Mr. Karim Babajani are also highly appreciated. Also, the authors would like to thank the anonymous reviewers and the editor for their insightful comments and suggestions.

\section{References}

AghaAlikhani M, Kazemi-Poshtmasari H, Habibzadeh F (2013) Energy use pattern in rice production: a case study from Mazandaran province, Iran. J Enconman 69:157-162. doi:10.1016/j.enconman.2013. 01.034

Annual agricultural statistics. Available from Ministry of Jihad-eAgriculture of Iran (2013) http://www.maj.ir

Bardi U, El Asmar T, Lavacci A (2013) Turning electricity into food: the role of renewable energy in the future of agriculture. J Clean Prod 53:224-231. doi:10.1016/j.jclepro.2013.04.014

Bojacá CR, Casilimas HA, Gil R, Schrevens E (2012) Extending the input-output energy balance methodology in agriculture through 
cluster analysis. Energ 47:465-470. doi:10.1016/j.energy.2012.09. 051

Chauhan NS, Mohapatra PKJ, Pandey KP (2006) Improving energy productivity in paddy production through benchmarking - an application of data envelopment analysis. Energy Convers Manage 47: 1063-1085. doi:10.1016/j.enconman.2005.07.004

Demircan V, Ekinci K, Keener HM, Akbolat D, Ekinci C (2006) Energy and economic analysis of sweet cherry production in Turkey: a case study from Isparta province. Energy Convers Manage 47:17611769. doi:10.1016/j.renene.2010.11.020

Eskandari Cherati F, Bahrami H, Asakereh A (2011) Energy survey of mechanized and traditional rice production system in Mazandaran Province of Iran. Afr J Agric Res 6(11):2565-2570. doi:10.5897/ AJAR 11.516

Food and Agriculture Organization (FAO) of the United Nation Statistics (2013) Retrieved February, Available from: http://www.faostat.fao. org.

Ghasemi Mobtaker H, Keyhani A, Mohammadi A, Rafiee S, Akram A (2010) Sensitivity analysis of energy inputs for barley production in Hamedan Province of Iran. Agr Ecosyst Environ 137:367-372. doi: 10.1016/j.agee.2010.03.011

Gilland B (2002) World population and food supply: can food production keep pace with population growth in the next half-century? Food Policy 27:47-63. doi:10.1016/S0306-9192(02)00002-7

Guangyong L, Xiaoyan L, Cuihong J, Guohua L (2011) Analysis on impact of facility agriculture on ecological function of modern agriculture. Procedia Environ Sci 10:300-306. doi:10.1016/j.proenv. 2011.09.049

Hasan MH, Mahlia TMI, Nur H (2012) A review on energy scenario and sustainable energy in Indonesia. Renew Sust Energ Rev 16(4): 2316-2328. doi:10.1016/j.rser.2011.12.007

Hokazono S, Hayashi K (2012) Variability in environmental impacts during conversion from conventional to organic farming: a comparison among three rice production systems in Japan. J Clean Prod 28: 101-112. doi:10.1016/j.jclepro.2011.12.005

Hong L-Y, Ming D-Z, Xi Z, Jiang W-H, Manda M, Nakanishi Y, Hong H$Z$ (2009) Effects of rice-duck mutualism on meat quality and slaughtering performance of duck. China Poult 31(5):20, http:// www.imna.ir/vdceop8p.jh8ffi9bbj.htm

Huang Y, Wang H, Huang H, Feng ZW, Yang ZH, Luo YC (2005) Characteristics of methane emission from wetland rice-duck complex ecosystem. Agr Ecosyst Environ 105:181-193. doi:10.1016/j. agee.2004.04.004

Huang S, Wang L, Liu L, Fu Q, Zhu D (2013) Nonchemical pest control in China rice: a review. Agron Sustain Dev 34(2):275-291. doi:10. 1007/s13593-013-0199-9

Hülsbergen KJ, Feil B, Biermann S, Rathke GW, Kalk WD, Diepenbrock W (2001) A method of energy balancing in crop production and its application in a long-term fertilizer trial. Agr Ecosyst Environ 86: 303-321. doi:10.1016/S0167-8809(00)00286-3

Isermann K (1994) Agriculture's share in the emission of trace gases affecting the climate and some cause-orientated proposals for sufficiently reducing this share. Environ Pollut 83:95-111. doi:10.1016/ 0269-7491(94)90027-2

Karkacier O, Goktolga ZG (2005) Input-output analysis of energy use in agriculture. Energy Convers Manage 46:1513. doi:10.1016/j. enconman.2004.07.011

Kibirige JS (1997) Population growth, poverty and health. Soc Sci Med 45(2):247-259

Kitani O (1999) CIGR Handbook of agricultural engineering. Energy and biomass engineering, Vol. 5. St Joseph, MI: ASAE Publication

Kizilaslan H (2009) Input-output energy analysis of cherries production in Tokat Province of Turkey. Appl Energ 86:1354-1358. doi:10. 1016/j.apenergy.2008.07.009
Kuesters J, Lammel J (1999) Investigations of the energy efficiency of the production of winter wheat and sugar beet in Europe. Eur J Agron 11:35-43. doi:10.1016/S1161-0301(99)00015-5

Li CF, Cao CG, Wang JP, Zhan M, Yuan WL, Shahrear A (2008) Nitrogen losses from integrated rice-duck and rice fish ecosystems in southern China. Plant Soil 307:207-217. doi:10.1007/s11104008-9597-1

Li S-S, Wei S-H, Zuo R-L, Wei J-G, Qiang S (2012) Changes in the weed seed bank over 9 consecutive years of rice duck farming. Crop Prot 37:42-50. doi:10.1016/j.cropro.2012.03.001

Lund V, Algers B (2003) Research on animal health and welfare in organic farming - a literature review. Livest Prod Sci 80:55-68. doi: 10.1016/S0301-6226(02)00321-4

Mingl MA, Sauerborn J (2006) Review of history and recent development of organic farming worldwide. Agr Sci China 5(3):169-178. doi:10.1016/S1671-2927(06)60035-7

Mosher JN, Corscadden KW (2012) Agriculture's contribution to the renewable energy sector: policy and economics - do they add up? Renew Sust Energ Rev 16(6):4157-4164. doi:10.1016/j.rser.2012. 03.027

Ong HC, Mahlia TMI, Masjuki HH (2011) A review on energy scenario and sustainable energy in Malaysia. Renew Sust Energ Rev 15(1): 639-647. doi:10.1016/j.rser.2010.04.009

Ozkan B, Ceylan RF, Kizilay H (2011a) Comparison of energy inputs in glasshouse double crop (fall and summer crops) tomato production. Renew Energ 36:1639-1644. doi:10.1016/j.renene.2010.11.022

Ozkan B, Ceylan RF, Kizilay H (2011b) Energy inputs and crop yield relationships in greenhouse winter crop tomato production. Renew Energ 36:3217-3221. doi:10.1016/j.renene.2010.11.022

Pahlavan R, Omid M, Akram A (2011) Energy use efficiency in greenhouse tomato production in Iran. Energ 36:6714-6719. doi:10.1016/ j.energy.2011.10.038

Panwar NL, Kaushik SC, Kothari S (2011) Role of renewable energy sources in environmental protection: a review. Renew Sust Energ Rev 15(3):1513-1524. doi:10.1016/j.rser.2010.11.037

Pin SU, Xiao-lan L, Ya Z, Huang H (2012) Influencing factors on rice sheath blight epidemics in integrated rice-duck system. J Integr Agr 11(9):1462-1473. doi:10.1016/S2095-3119(12)60146-4

Pishgar-Komleh SH, Sefeedpari P, Rafiee S (2011) Energy and economic analysis of rice production under different farm levels in Guilan province of Iran. Energ 36:5824-5831. doi:10.1016/j.energy.2011. 08.044

Rafiee S, MousaviAvval SH, Mohammadi A (2010) Modeling and sensitivity analysis of energy inputs for apple production in Iran. Energ 35:3301-3306. doi:10.1016/j.energy.2010.04.015

RaiJadidi M, Homayonifar M, Sobohisaboni M, Kerdmand V (2010) Study performance and energy efficiency in tomato production. J Agr Econ Dev 24(3):363-370 (In Persian)

Royan M, Khojastehpour M, Emadi B, Ghasemi Mobtaker H (2012) Investigation of energy inputs for peach production using sensitivity analysis in Iran. Energy Convers Manage 64(3):441-446. doi:10. 1016/j.enconman.2012.07.002

Sarkar A, Aronson K, Patil S, Hugar LB, VanLoon GW (2012) Emerging health risks associated with modern agriculture practices: a comprehensive study in India. Environ Res 115:37-50. doi:10.1016/j. envres.2012.03.005

Sayin C, Mencet M, Ozkan B (2005) Assessing of energy policies based on Turkish agriculture: current status and some implications. Energy Policy 33:2361-2373. doi:10.1016/j.enpol.2004.05.005

Shahan S, Jafari A, Mobli H, Rafiee S, Karimi M (2008) Energy use and economical analysis of production in Iran: a case study from Ardabial province. J Agr Tech 4(1):77-88. doi:10.1016/j. enconman.2008.07.003

Singh S, Singh S, Mittal JP, Pannu CJS, Bhangoo BS (1994) Energy inputs and crop yield relationships for rice in Punjab. Energ 19(10):1061-1065. doi:10.1016/0360-5442(94)90094-9 
Singh S, Singh S, Pannu CJS, Singh J (2000) Optimization of energy input for raising cotton crop in Punjab. Energ Convers Manage 41: 1851-1861. doi:10.1016/S0196-8904(00)00027-3

Singh H, Mishra D, Nahar NM, Ranjan M (2003) Energy use pattern in production agriculture of a typical village in arid zone India: part II. Energ Convers Manage 44(7):1053-1067. doi:10.1016/S01968904(01)00161-3

Swaminathan MS (2010) Achieving food security in times of crisis. N Biotechnol 27:453-460. doi:10.1016/j.nbt.2010.08.002

Tabatabaie SMH, Rafiee S, Keyhani A, Ebrahimi A (2013) Energy and economic assessment of prune production in Tehran province of Iran. J Clean Prod 39:280-284. doi:10.1016/j.jclepro.2012.07.052

Takayama K, Hirano N, Nakanishi Y, Manda M (2004) The influence of free-ranging adult aigamo ducks on emerging weeds, pest insect infestation, rice production on paddy fields in southern Shan state, Union of Myanmar. Japan J Livest Manage 39:143-150

William F, Dean D (2008) Energy and duck. Cornell university. Available at web site http://www.duckhealth.com. http://www.ifoam.bio/
Xi Y-G, Qin P (2009) Energy evaluation of organic rice-duck mutualism system. Ecol Eng 35:1677-1683. doi:10.1016/j.ecoleng.2007.11. 006

Yates DS, Moore DS, Starnes DS (2008) The practice of statistics, 3rd edn. W. H. Freeman and Company, New York

Yilmaz I, Akcaoz H, Ozkan B (2005) An analysis of energy use and input-output costs for cotton production in Turkey. Renew Energ 30:145-155. doi:10.1016/j.renene.2004.06.001

Yuksel I, Kaygusuz K (2011) Renewable energy sources for clean and sustainable energy policies in Turkey. Renew Sust Energ Rev 15(8): 4132-4144. doi:10.1016/j.rser.2011.07.007

Zangeneh M, Omid M, Akram A (2010) A comparative study on energy use and cost analysis of potato production under different farming technologies in Hamadan province of Iran. Energ 35:2927-2933. doi:10.1016/j.energy.2010.03.024

Zhan M, Cao CG, Wang JP, Jiang Y, Cai ML, Yue LX, Shahrear A (2011) Dynamics of methane emission, active soil organic carbon and their relationship in wetland integrated rice-duck systems in southern China. Nutr Cycl Agroecosys 89:1-13 